\title{
Educação e leitura popular na sociedade barroca brasileira: contribuições da arte franciscana
}

\author{
Luiz Fernando Conde Sangenis ${ }^{1}$
}

\section{Resumo}

Tratamos da atividade leitora, na sociedade colonial brasileira, sob uma perspectiva ampliada do texto produzido ao alcance das camadas populares. Simples e iletrados encontraram nas leituras ouvidas e nas leituras de imagens uma maneira peculiar de adquirir o saber que compartilhavam com intelectuais e potentados. A arte barroca, particularmente as contribuições artísticas sob a inspiração franciscana, e as suas formas visuais e auriculares de tratar o discurso, sem a representação estritamente escrita, são a matéria com a qual nos propusemos a trabalhar para encontrar o âmago da atividade popular leitora. Esta habilidade leitora do povo é o resultado de processos mais complexos e abrangentes da educação dos sentidos.

Palavras-chave: Arte barroca; Arte franciscana; Leitura visual; Leitura ouvida; Educação popular.

\section{Education and popular reading in Brazilian baroque society: contributions of franciscan art}

\begin{abstract}
In this paper, we deal with the reading activity in Brazilian colonial society, from an extended perspective of the text that was produced within the reach of the popular layers. Simple and illiterate people found in the heard readings and in the readings of images a peculiar way of acquiring the knowledge that they shared with the intellectuals and powerful men. Baroque art, particularly the artistic contributions under Franciscan inspiration, and its visual and auricular forms of dealing with discourse, without the strictly written representation, are the matter with which we set to work in order to find the core of popular reading activity. This reading ability of the people is the result of complex and comprehensive processes of the education of the senses.
\end{abstract}

Keywords: Baroque art; Franciscan art; Visual reading; Heard reading; Popular education.

\section{Educación y lectura popular en la sociedad barroca brasileña: contribuciones del arte franciscana}

\section{Resumen}

Tratamos de la actividad lectora en la sociedad colonial brasileña, desde una perspectiva ampliada del texto producido y al alcance de las capas populares. Simples e iletrados encontraron en las lecturas oídas y en las lecturas de imágenes una manera peculiar de adquirir el saber que compartían con intelectuales y potentados. El arte barroca, particularmente las contribuciones artísticas bajo la inspiración franciscana y sus formas visuales y auriculares de tratar el discurso, sin la representación estrictamente escrita, son la materia con la que nos propusimos trabajar para encontrar el núcleo de la actividad popular lectora. Esta habilidad lectora del pueblo es el resultado de procesos más complejos y completos de la educación de los sentidos.

Palabras clave: Arte barroca; Arte franciscana; Lectura visual; Lectura escuchada; Educación popular.

\section{Introdução}

O ato de ler é uma função essencial de todos os seres humanos. Para Manguel (1999, p.20), ler é "quase como respirar". Para além do texto escrito, somos leitores de muitos outros

\footnotetext{
${ }^{1}$ Universidade do Estado do Rio de Janeiro - UERJ, Niterói, Ifsangenis@gmail.com Periódico Horizontes - USF - Itatiba, SP - Brasil - e019039
} 
textos. Estamos, portanto, universalmente aptos à função leitora, inclusive aqueles que desconhecem as letras. Com esta compreensão, Manguel (1999, p.19) nos adverte: "ler as letras de uma página é apenas um dos seus muitos disfarces". Segundo o autor, assim é que o astrônomo lê o céu estrelado, o zoólogo lê os rastros de animais na floresta, o público lê os movimentos da dançarina no palco, o tecelão lê o desenho tecido no tapete, o organista lê as linhas musicais na partitura, os pais leem o rosto do bebê, o adivinho chinês lê as marcas na carapaça da tartaruga, o amante lê o corpo da amada sob os lençóis, o psiquiatra ajuda os pacientes a lerem os seus sonhos perturbadores. Tal sucessão de exemplos, bem mais extensa, na obra de Manguel, tem a finalidade de evidenciar o enorme espectro de possibilidades leitoras.

Esta perspectiva ampliada do texto, dos sujeitos leitores e da leitura dá outra dimensão ao modo de concebermos a literatura, especialmente, nas circunstâncias da sociedade barroca brasileira. Os condicionantes culturais vigentes na Colônia são, em larga medida, antiliterários. Sua marca mais forte é desenhada por uma população majoritariamente desescolarizada, iletrada e, portanto, não leitora do texto escrito. Pois como percebeu Bosi (2009, p.2), “o domínio do alfabeto, reservado a poucos, serve como divisor de águas entre a cultura oficial e a vida popular. O cotidiano colonial popular se organizou e se reproduziu sob o limiar da escrita". Daí a nossa escolha, neste texto, em tratar da leitura, no sentido mais amplo possível, sob a ótica dos leitores que, se não vivem apartados, estão muito afastados da cultura ilustrada, assentada nos livros e nos códigos literários clássicos de domínio exclusivo da elite colonial, e cuja principal referência é subsidiária da cultura metropolitana.

Da Europa recebemos o barroco. A partir do século XVII, o Brasil amadureceu sob seu signo. Assim como em outras partes do mundo, no Brasil, o barroco foi um estilo movido pela inspiração religiosa. Num tempo em que o religioso educava as almas, o catolicismo, em oposição ao protestantismo, após o Concílio de Trento, percebeu que, em benefício da fé, a arte pode seduzir a alma, perturbá-la e encantá-la, emocioná-la nas profundezas não percebidas pela razão. Mas entendemos que a prodigalidade estética da arte barroca, mais que prestar um tributo a Deus por sua própria glória, pretendeu servir ao colonizador de meio eficaz de aculturação. $O$ intento era conduzir as gentes nativas e aquelas aqui chegadas em direção à apreciação das virtudes abstratas cristãs, buscando atraí-las, antes pelos sentidos materiais, especialmente através da beleza das formas. A "colonização do imaginário" (GRUZINSKI, 2003)

$$
\text { Periódico Horizontes - USF - Itatiba, SP - Brasil - e019039 }
$$


das gentes não europeias não foi o único movimento produzido. Também os colonizadores adotaram diversos elementos da cultura nativa. "A história do Brasil colonial está repleta de exemplos de ambos os processos de 'aculturação às avessas'” (VAINFAS, 2014, p.360). A arte barroca enriqueceu o substrato cultural sobre o qual germinou uma peculiar mestiçagem, ao facilitar o surgimento de catalizadores culturais que modificaram a leitura e a interpretação das gramáticas culturais em conflito.

A arte barroca, com maior ou menor intencionalidade, favoreceu o que Le Breton (2016, p.32) nomeou de "modelação cultural dos sentidos". Uma dialética sutil se exerce entre a língua e as percepções. Os mediadores culturais produzidos pela arte barroca, dotados de intensa capacidade de afetar a sensibilidade, contribuíram de forma decisiva para uma reorganização sensorial das gentes que viviam na colônia.

O objetivo principal deste trabalho é o de nos aproximarmos de outras possibilidades leitoras ao alcance das camadas populares no Brasil Colônia. Os simples e iletrados encontraram nas leituras ouvidas e nas leituras de imagens uma maneira peculiar de adquirir um saber que compartilhavam com os intelectuais e potentados. Trataremos de uma sintaxe sem a representação estritamente escrita, ainda que se deva considerar que o texto escrito é o fundamento das demais artes. A arte barroca, particularmente as contribuições artísticas sob a inspiração franciscana, e as suas formas visuais e auriculares de tratar o discurso - o sermão dos pregadores, as composições musicais litúrgicas, as produções cênicas de cunho catequético e as obras plásticas sacras -, são a matéria com a qual nos propusemos a trabalhar para encontrar o âmago da atividade popular leitora. Entendemos que esta habilidade leitora do povo é o resultado de processos mais complexos e abrangentes de educação que se produziu em âmbitos extraescolares.

\section{A arte barroca no Brasil}

O Barroco surgiu no Brasil após o primeiro século da colonização. Não foi a primeira forma que tomou a arte colonial. Coube ao Maneirismo esse papel inaugural. Maneirismo este sujeito às condições existentes, submetido às muitas limitações materiais e humanas, típicas de uma terra hostil em que a exuberância da natureza selvagem e inexplorada lançava desafios mais

$$
\text { Periódico Horizontes - USF - Itatiba, SP - Brasil - e019039 }
$$


prementes às necessidades utilitárias de sobrevivência e de fixação dos conquistadores. Os primeiros núcleos humanos, cidadelas construídas de madeira e pouca pedra e cal, tentavam conciliar arquitetonicamente os lugares de moradia, de culto, de administração e de defesa contra povos indígenas nem sempre amigáveis e invasores "estrangeiros" do ultramar. De inspiração europeia, por tantas causas inescapáveis e urgentes, os artistas coloniais desses inícios tiveram de encontrar, por aqui, de fato, a sua maneira de produzir a arte.

Iniciado o século XVII, período em que ainda eram dedicados esforços ingentes para fundar uma infraestrutura essencial nos núcleos urbanos litorâneos, o Barroco logo foi ganhando destaque na vida cultural brasileira e tornou-se a sua mais viva expressão.

Nascido sob o signo do Barroco, o Brasil tem sua fisionomia e alma compostas até hoje de seu sopro místico. Aqui o Barroco não foi um estilo artístico passageiro, mas a substância básica de toda uma nova síntese cultural. Se há um traço que perpassa as diferentes manifestações da cultura brasileira, é justamente esse barroquismo latente, com as vibrações e ressonâncias que the são típicas: extremos da fé, cupidez do poder, anseios messiânicos, ilusão de grandeza, impulso da contradição, exaltação dos sentidos, êxtase da festa, convivências das disparidades, atração das vertigens, mágica das palavras, sonho da glória, pendor para o exuberante e o monumental, gosto da tragédia, horror da miséria e compulsão à esperança. Não cabe, portanto, falar de uma era do Barroco, sendo mais apropriado tentar entender essa dimensão barroca profunda que assinala toda a história do Brasil (SEVCENKO, 2000, p.39).

Da expressão literária - se é que foi primeva, ainda que sem tanto desenvolvimento ao longo dos séculos XVII e XVIII, pois não havia um público leitor e nem as condições para a formação de uma consciência literária brasileira - o barroco deu inspiração às demais manifestações artísticas: arquitetura, escultura, pintura, música, teatro. Sem dúvida, as artes visuais e arquitetônicas, concentradas no tema sacro, foram as mais potentes e aquelas que conseguiram atingir um grau superlativo. A música barroca é a arte menos conhecida e a que deixou poucas relíquias. As partituras mais antigas quase todas se perderam, e se não fossem os testemunhos escritos, desconheceríamos a intensa atividade musical brasileira, desde o início do barroco (CASTAGNA, 2008).

A mão forte e pesada da Metrópole, aplicada a uma intencionalidade crescente de exploração da colônia, incitou o incremento da escravidão, antes restrita ao elemento indígena, 
buscando, na África, os negros que, pouco a pouco, formaram a base principal da força produtiva. Também, nesse século, houve significativa expansão do território, em direção ao interior do continente, com destaque à descoberta de ouro e pedras preciosas em Minas Gerais. Estão postos, então, os condicionantes essenciais para o desenvolvimento da arte barroca na colônia: na Bahia, sede administrativa e importante núcleo comercial; em Pernambuco e no Maranhão e Grão Pará, não obstante a invasão de holandeses e de franceses, houve grande prosperidade; em Minas Gerais, de forma bastante peculiar, o enriquecimento repentino foi sem precedentes; e no Rio de Janeiro, para onde, mais tarde, se transfere a administração colonial. Eram regiões que, em razão das riquezas produzidas, principalmente, pela cana de açúcar cultivada em regime de plantation, pela exploração de drogas do sertão ou pela extração de minério, permitiram o surgimento de cidades mais ricas e dinâmicas, com populações crescentes, e de constituição étnica variada. A forma exuberante que a arte barroca foi tomando, no Brasil, é, em boa medida, resultado da melhora das condições materiais locais e regionais, bem como da criatividade dos artistas que, da Europa, encontraram motivações espirituais ou puramente econômicas para atravessar o Atlântico, ou dos que, por aqui nascidos, aprenderam, com a vida e com inato talento, a superar os mais renomados mestres.

A superação de que falamos não se funda na comparação que se possa fazer com o barroco europeu, este considerado central, de caráter acadêmico, erudito, sofisticado e puro. Lemos do historiador francês Victor Tapié (1991, p.354, tradução minha) a afirmação: “Não há dúvida de que a Europa possui as mais belas obras barrocas, embora os europeus não se orgulhem disso"2. Há os que insistem em comparar o barroco colonial com o europeu classificando o nosso de pobre e tecnicamente pouco competente, dependente dos modelos europeus, de modo que o resto do que se produziu em outras regiões do mundo não passava de irradiação periférica e marginal (CONCHA, 2013, p.139). Tese eurocêntrica sem dúvida, todavia ainda compartilhada por vários estudiosos da arte barroca sul-americana, dentre os quais se destaca Graziano Gasparini (1995).

Não custa repetir que o ambiente colonial, ao menos, nos dois primeiros séculos da colonização, foi marcado pela pobreza e escassez. Pois conforme havia dito o Padre Nóbrega,

\footnotetext{
${ }^{2}$ No cabe duda de que Europa posee las obras barrocas mas hermosas, aunque los europeos no se sintam demasiado orgulhosos de ello.
} 
“estamos em terra tão pobre, que nada se ganha com ela, porque é gente tão pobre, que por mais pobres que sejamos, somos mais ricos que eles" (NÓBREGA, 1955, p.391). O nosso barroco, de execução técnica mais tosca, não raro, feita por mãos indígena, negra ou mestiça, guarda traços genuínos da arte popular, sem que isso implique qualquer demérito. Evidente que tal produção, haja vista que, nas oficinas, os artistas com formação técnica mais sólida eram poucos, tinha como nota comum o autodidatismo dos artesãos.

Em acervos museológicos, encontramos uma quantidade de peças que testemunham o gênio indígena dedicado às artes sacras, oriundas das missões jesuíticas do sul do país, e de alguns aldeamentos nordestinos e grão-maranhenses. De igual modo, "a mão afro-brasileira" (ARAUJO, 2010) deu às artes barrocas um aspecto singular, ora reproduzindo, ora interferindo e alterando de modo intencional a estética da Europa. Virgens e cristos mestiços, negros e indígenas, santos de pele negra, e toda sorte de imagens santificadas, cujas feições lembram bem mais os nativos da terra. Um dos exemplos mais paradigmáticos é o de Mestre Ataíde e suas "Marias mulatas" (OLIVEIRA, 2011, p.99) pintadas em diversas igrejas mineiras, com destaque para Nossa Senhora dos Anjos da Porciúncula, sua mais afamada composição, feita no forro da Igreja São Francisco de Assis em Ouro Preto. Segundo D’Araujo (2000), o pintor teria usado como modelos para os anjos seus próprios filhos e para a Virgem mulata, sua companheira.

Dentre os primeiros religiosos que atuaram no Brasil, das mais diversas nacionalidades, vários exerceram ofícios de artesãos, ourives, pintores, escultores, arquitetos, literatos, musicistas e deram inestimável contribuição a esta complexa configuração do barroco colonial brasileiro. Mantiveram-se mais fiéis aos cânones da arte sacra europeia, portuguesa, italiana ou francesa.

A partir do século XVII, entretanto, quase todos os importantes artistas "eram mulatos ou tinham a 'infâmia do mulato' no sangue” (ICI, 1994, p.7). Certamente, por não estarem tão sujeitos aos controles eclesiásticos, por motivações subjetivas ou mesmo políticas, agiam desobrigados a cumprir convenções ou cânones que tendiam a se dissipar, conforme o tempo e o espaço de sua ação.

Não foi tranquila, certamente, a aceitação de uma Nossa Senhora negra cercada de tantas outras figuras celestes igualadas na cor. Em que pesem as particularidades da sociedade mineira, bastante mestiçada, de modo que o mestiço não é apenas um símbolo da essência do brasileiro,

Periódico Horizontes - USF - Itatiba, SP - Brasil - e019039 
mas a marca identitária comum da zona mineradora, havia uma dificuldade de associação da cor negra ou mestiça com a santidade. De acordo com a mentalidade corrente, a santidade e a cor negra, e mesmo a parda, por estar contaminada de "sangue infecto" (o designativo utilizado à época para os que possuíam ascendência negra, moura ou judia), se repugnavam. Contra esta concepção discriminatória, a tese franciscana de Frei Jaboatão foi corajosa e inovadora, conforme trataremos mais adiante.

\section{A arte literária barroca no Brasil}

"Prosopopeia", poema épico de 1601, de autoria de Bento Teixeira, no âmbito da história da literatura colonial brasileira, é a primeira dicção poética do barroco. Entre os críticos, tornouse comum dizer que o seu valor histórico avulta o literário. Segundo Brandão (2001, p.49), os versos de Bento Teixeira são decalcados na épica camoniana, todavia sem conseguir manter a qualidade sintático-estrófica do autor de "Os Lusíadas".

Um século depois, o poeta Manuel Botelho de Oliveira, autor de "Música do Parnaso" (1705), primeiro livro impresso de autor nascido no Brasil, reuniu poemas de sua lavra, em português e espanhol, de influência cultista e conceptista, estilos também chamados, respectivamente, de gongorismo e quevedismo. Mais tarde, surge a poesia do Frei Manuel de Santa Maria Itaparica, também da escola camoniana, com destaque para "Eustáquidos" (1769), poema sacro e tragicômico, em que se contém a vida de Santo Eustáchio, mártir. A grande nota da poesia colonial é a imitação poética. Fixados às correntes e aos modelos clássicos de gregos, latinos, espanhóis, italianos e portugueses, os autores não escondem suas fontes e mimetizam os seus antecessores, especialmente os já canonizados pela opinião. O que aos críticos do passado pareceu plágio, "era antes uma homenagem e um atestado de bons antecedentes poéticos, que o poeta fazia questão de expor" (BRANDÃO, 2001, p.13).

Momentos mais altos do processo de formação da literatura brasileira são identificados por Sérgio Buarque de Holanda na obra poética de Cláudio Manuel da Costa, a quem dedica quase duzentas páginas de "Capítulos da literatura colonial" (1991). Elevado grau de interesse ganha de outros autores a poesia de Gregório de Matos, sem dúvida, um dos mais originais expoentes da literatura colonial. Ao inverter o tom lírico em satírico, não deixa de seguir "as

$$
\text { Periódico Horizontes - USF - Itatiba, SP - Brasil - e019039 }
$$


formas regradas pelas quais se permitia a atuação do espírito dionisíaco com sua verve popular, sensorial e mesmo grosseira" (BRANDÃO, 2001, p.14). O Boca do Inferno, alcunha atribuída ao poeta em razão de suas contundentes críticas sociais satíricas, também produziu grande número de textos religiosos que tratam do pecado e da salvação dos homens.

Mas a poesia lida ou recitada, não obstante seu uso frequente, como material educativo, limitou-se a círculos restritos e elitizados. A literatura ganhará os ouvidos populares, nas igrejas e nas praças, onde a prosa dos pregadores e as festas populares alcançavam todos os estratos sociais.

Holanda (1995, p.44), na tentativa de compreender a colonização portuguesa, tipificada de "aventureira", em contraste com outro tipo de colonização que se caracterizou pela "ética do trabalho", resumiu-a numa frase de feito: "seu ideal será colher o fruto sem plantar a árvore". O colonizador aventureiro visou à exploração dos recursos naturais e do elemento humano, o enriquecimento rápido e o retorno a Portugal. Não fez questão de desenvolver a cultura dos territórios explorados, e, por séculos, a educação, sob a tutela da Igreja, foi delegada aos religiosos que ministravam a instrução elementar com finalidade catequética.

Grande parte da população era analfabeta, não havia bibliotecas ou escolas públicas, a imprensa era proibida, manuscritos eram raros, na medida em que o papel era escasso e custoso. Os poucos livros que circulavam passavam pela censura estatal e eclesiástica, e os títulos disponíveis podiam ser classificados em vida de santos, catecismos, gramáticas de língua latina e de algumas línguas indígenas, também para uso catequético, compêndios de leis civis ou eclesiásticas, além de uns poucos romances de cavalaria. $\mathrm{O}$ diminuto número de virtuais leitores não tinha o que ler. Para os mais abastados, o estudo no velho continente era um caminho possível.

No Brasil, o âmbito eclesiástico foi o nicho onde as letras encontravam cultivo. Daí que o aprimoramento possível estava ao alcance dos que ingressavam no clero secular, mas, sobretudo nos conventos das ordens religiosas existentes no Brasil (franciscanos, jesuítas, beneditinos carmelitas e mercedários). A formação oferecida nos conventos foi capaz de produzir intelectuais da mais alta qualidade, sem que precisassem ir à Europa. Apenas a partir do século XVIII, a literatura começará a adquirir maior vigor e uma feição mais nativa, pari e passu ao movimento de urbanização das regiões litorâneas e, no caso dos sertões, à descoberta e exploração aurífera em Minas Gerais.

A arte literária barroca ganhou contornos mais densos com a prosa religiosa, em forma Periódico Horizontes - USF - Itatiba, SP - Brasil - e019039 
de sermão. Os autores jamais deixaram de fazer menção ao jesuíta português Padre Antônio Vieira e aos seus conhecidos e decantados sermões. Poucos, no entanto, têm estudado a produção manuscrita e impressa dos frades franciscanos. De referência recomendada, figura Frei Cristóvão de Lisboa, cujo nome enuncia a sua naturalidade lusitana. Designado primeiro Custódio no Maranhão, "trinta anos antes de Vieira, Frei Cristóvão foi pioneiro no trabalho hercúleo de defender os direitos e as liberdades dos índios" (AMORIM, 2005, p.179). O frade é autor de duas dezenas de obras impressas compostas basicamente de sermões, dentre os quais se destaca "Santoral de vários sermões de santos", de 1638, e "Jardim da sagrada escritura disposto em modo alfabético", de 1653. O pernambucano Frei Antônio de Santa Maria Jaboatão, também deve ser celebrado. É autor de "Jaboatão místico em correntes sacras dividido", de 1758, e do manuscrito "Obras acadêmicas e outras várias prosas e versos feitas e recitadas na Academia dos Renascidos", de 1759, jamais editado, e sob a guarda do Arquivo Franciscano do Recife. Ambas as obras são compostas de sermões. Frei Jaboatão é reconhecido como poeta, genealogista, mestre formador e cronista oficial de sua província religiosa, acadêmico pertence a duas academias literárias baianas de seu tempo, a dos Renascidos e a dos Esquecidos. Um dos seus mais notáveis sermões, "Discurso histórico, geográfico, genealógico, político e encomiástico, recitado em a nova celebridade, que dedicaram os pardos de Pernambuco ao santo de sua cor o Beato Gonçalo Garcia”, editado em Lisboa, em 1751, foi redigido e proclamado, na cidade de Recife, em defesa da mestiçagem, ao exaltar a cor parda ou mestiça, considerada mais perfeita que a branca ou a negra. Em seu discurso, Jaboatão exalta antes a cor do que a santidade do “Pardo Santo" (JABOATÃO, 1758, p.168), pois a santidade já fora atestada pela Igreja por se tratar de um mártir. Defesa que o faz precursor de Euclides da Cunha, Manoel Bonfim e Gilberto Freyre, antecedendo-os em um século e meio.

Falamos dos franciscanos, não apenas motivados para compensar uma ausência ou um esquecimento histórico recorrente. Falamos porque a espiritualidade franciscana marca sensivelmente o catolicismo barroco, inspirando os seus símbolos, as suas imagens, os seus sons. Quantas são as igrejas e outras construções coloniais dedicadas a Santo Antônio, à Conceição Imaculada de Maria e a sua Assunção, a São Benedito e ao próprio São Francisco! Todos esses santos franciscanos ganharam a preferência dos negros e foram sincretizados com os inquices, orixás e voduns das religiões de matriz africana. 
Vainfas (2014, p.357), em inspirado capítulo que intitula "A tessitura dos sincretismos: mediadores e mesclas culturais", ao considerar as múltiplas faces dos "mediadores culturais", no sentido que Michel Vovelle deu ao termo, quando trata dos religiosos, se restringe aos jesuítas. Repetindo Bosi (2009) que, na sua "Dialética da Colonização" também só versa sobre os religiosos jesuítas, Vainfas (2014, p.372) exalta Anchieta "como o principal mediador cultural das hostes jesuíticas", haja vista seus jogos de traduções e de composições gramaticais que mesclavam as culturas indígenas com o catolicismo. Bem mais dialéticos e plurais seriam os autores, caso envolvessem também os franciscanos e demais religiosos que se dedicaram às mesmas causas.

Quanto aos franciscanos, carecem que lhes escrevam um capítulo que os distinga como mediadores culturais, ao modo com que os jesuítas foram reconhecidos. E não faltariam motivos. Frei Francisco do Rosário, o primeiro que pisou as terras do Maranhão, escreveu um "Tratado sobre os Ritos, Costumes e Línguas dos Brasis" e, na língua indígena, um "Catecismo para o Gentio do Brasil", livros que se perderam. Das várias obras do já mencionado Frei Cristóvão de Lisboa, acrescemos a sua "História dos Animais e Árvores do Maranhão", que o tornou o mais antigo naturalista da Amazônia. Frei João de Santo Atanásio, o iniciador das missões franciscanas no Jari, compôs um "Roteiro moral" para missionários e mais um "Roteiro doutrinal". Frei Boavista de Santo Antônio escreveu artes e vocabulários das línguas Aruan e Sacaçá. Frei Joaquim da Conceição e Frei Mateus de Jesus Maria fizeram catecismos, súmulas, gramáticas e vocabulários dos Aruan, Aracaju e Maraumi. Frei Mateus e Frei João de Jesus ocuparam-se com a língua geral. Frei Vicente do Salvador é o autor da primeira história do Brasil escrita por um brasileiro nato (RÖWER, 1947). Tantos! Mas não se cita um sequer...

\section{A grande aula popular de leitura}

A arte barroca, no Brasil, amalgamou-se à religião, sobretudo à católica. Não havia, na colônia, uma corte, nem muitos palácios de governo a erguer com ornamentos ante a profusão de templos religiosos. Daí que o principal mecenas da arte barroca brasileira foi a Igreja e suas variadas instituições, algumas Sés episcopais, as ordens religiosas, ordens e confrarias de leigos àquelas ligadas, e irmandades, as mais diversas, desde que constituídas por membros abastados. 
Os franciscanos do nordeste brasileiro, no Século XVII, tiveram o mérito de erguer alguns dos principais marcos arquitetônicos do barroco. Segundo Sousa (2005), a igreja do convento franciscano de Cairu ${ }^{3}$, na Bahia, projeto audacioso e inventivo de autoria de Frei Daniel de São Francisco (1600-1692), foi o primeiro templo construído no Brasil que se afiliou ao barroco. Foi, mesmo, duplamente pioneiro, pois surgiu antes que uma fachada barroca aparecesse em Portugal. Criação de grande originalidade em que se mesclam traços provenientes da renascença italiana, do maneirismo alemão e do classicismo seiscentista lusitano, a igreja de Cairu foi uma invenção brasileira que não tinha similares nos países europeus de arquitetura renomada. Foi ainda o primeiro alçado de igreja de concepção erudita erguida no Brasil que não seguiu o modelo português. No universo das frontarias originais de igrejas do Brasil colonial, originou uma verdadeira escola arquitetônica. Foram cinco as fachadas que derivaram dela: as das igrejas franciscanas de Paraguaçu, Igaraçu, Recife, Olinda e João Pessoa. As de Igaraçu e Recife seguiram o modelo de Cairu, talvez por influência direta de Frei Daniel. Apesar de todos esses méritos, para os quais nossa historiografia ainda não atentou, quase nunca a imagem dessa igreja é mostrada nos livros brasileiros de história da arquitetura.

O templo católico, mais que um lugar de culto, era o mais importante espaço de socialização do povo, um centro difusor de educação e de valores sociais básicos, e, com frequência, um local seguro a que se acorria quando a vida da colônia se fazia turbulenta (COSTA, 2002). O objetivo central dos religiosos era a doutrina e a catequese, de modo que as igrejas se ergueram amplas, geralmente, em nave única, igrejas salões, verdadeiras salas de prédica ou aulas, sendo o termo aula, aqui, considerado na sua acepção latina e cujo significado originário, no âmbito da arquitetura, designava o lugar do parlatório.

A decoração interior das igrejas, ricamente composta de esculturas ornamentais em madeira dourada, é o prolongamento da arquitetura e frequentemente a razão de ser do templo. Segundo Bazin (1956), os intercâmbios entre a decoração e a arquitetura são tão fortes que é praticamente impossível separá-los. O altar mor, para onde tudo converge, clímax de tão variados e belos conjuntos decorativos, exibem, em esplendor, o santo orago principal do templo, enquanto os diversos altares laterais, dispostos ao longo da nave, como pequenas

\footnotetext{
${ }^{3}$ As imagens da igreja e do convento podem ser visualizadas em http://www.ofmsantoantonio.org/?page_id=994. Acesso em: 2 mai. 2018.
}

Periódico Horizontes - USF - Itatiba, SP - Brasil - e019039 
apoteoses, seguindo a uma ordem hierárquica e a disposições afetivas e devocionais, exibem os demais santos para a veneração. A pintura dos tetos e das paredes completa um cenário estético com finalidades didáticas. Os medalhões emoldurados no teto, fingimento de céu, descrevem os mistérios da Igreja. Nas laterais, em frisas, que vão do meio ao chão, abaixo dos nichos das imagens dos santos, no batistério, na sacristia, na capela mor, a pintura é, em geral, hagiográfica, narrando os fatos ligados aos principais personagens da Igreja, tendo como referência os Testamentos Sagrados ou o hagiológio afeito aos grupos fundadores do templo, no mais genuíno sentido da escrita pictórica.

Evidente que o padrão decorativo dos interiores das igrejas segue uma tradição que remonta os primeiros séculos do cristianismo. Manguel exemplifica as finalidades decorativas dos templos religiosos valendo-se dos escritos de São Nilo de Ancira (hoje, Ancara, capital da Turquia) e que veio a falecer por volta do ano de 430. As virtudes e a vida heroica do santo, monge pertencente a uma ordem ascética do Monte Sinai, conferiram-Ihe grande autoridade. Em uma das muitas cartas do santo que se conservaram, são descritos "certos traços ideais de decoração eclesiástica" (MANGUEL, 1999, p.117). O bispo Olimpidoro, no desejo de construir e decorar uma igreja, consultou a São Nilo sobre os temas que deveriam ser pintados no interior do templo. Na referida missiva, São Nilo orientou ao bispo que conservasse parte do intento original de decorá-la com imagens de santos, e sugere acrescer cenas do Velho e do Novo Testamentos. Argumentava o monge que tais cenas "serviriam 'como livros para os iletrados, ensinando-lhes a história bíblica e incutindo neles a crônica da misericórdia de Deus'” (MANGUEL, 1999, p.117).

A sequência da narrativa verossimilhante do autor completa-nos o entendimento.

São Nilo imaginava os crentes analfabetos aproximando-se dessas cenas em sua igreja funcional e lendo-as como se fossem as palavras de um livro. [...] imaginavaos identificando as imagens preciosas, ligando-as mentalmente umas às outras, inventando histórias para elas ou associando as imagens familiares associações com os sermões que tinham ouvido, ou então se não fossem totalmente 'iletrados', com exegeses das Escrituras (MANGUEL, 1999, p.117).

Dois séculos depois, o Papa Gregório, o Grande, faria eco às ideias de Nilo. Manguel reproduz as palavras do Papa colhidas em citação feita por Claude Dagens (1997):

Periódico Horizontes - USF - Itatiba, SP - Brasil - e019039 


\begin{abstract}
Uma coisa é adorar imagens, outra é aprender em profundidade, por meio de imagens, uma história venerável. Pois o que a escrita torna presente para o leitor, as imagens tornam presente para o analfabeto, para aqueles que só percebem visualmente, porque nas imagens os ignorantes veem a história que têm de seguir, e aqueles que não sabem as letras descobrem que podem, de certo modo, ler. Portanto, especialmente para a gente comum, as imagens são equivalentes à leitura (MANGUEL, 1999, p.117).
\end{abstract}

Valendo-se de citação de Umberto Eco (1970), lembra Manguel (1999, p.117-118) que o Sínodo de Arras, em 1025, "declarou que 'aquilo que a gente simples não podia aprender lendo as escrituras poderia ser aprendido por meio da contemplação de imagens'”. Tais imagens portadoras de narrativas, de alegorias, de símbolos e de convenções significantes, na época, de domínio público - tornavam as igrejas a Bíblia dos analfabetos.

Mas é na Renascença que o visual ganhará a autoridade e a importância que outrora pertencera à audição. "O olho é celebrado como a janela da alma" (LE BRETON, 2016, p.47). As igrejas ornadas pelos grandes artistas do Renascimento serão templos ornados para o gozo da visão.

A leitura ouvida foi outra importante forma de fazer a população iletrada ler o que não pôde fazer com os olhos. A educação consiste, ela também, em uma escuta. Eis a importância das prédicas, dos sermões que, indistintamente, alcançavam da elite ao mais baixo populacho.

A prática de ler com os ouvidos é também antiga. "Desde a Antiguidade, para as sociedades europeias, a transmissão da cultura e das maneiras de estar juntos foi obra da palavra" (LE BRETON, 2016, p.45). Testemunho dos tempos do Império Romano menciona o hábito de se entreter durante as refeições com a leitura em voz alta (MANGUEL, 1999, p.139). Da recepção dos textos sagrados à das tradições, o mundo era regido pela oralidade. A tradição talmúdica é a parte relevante da valorização da escuta: com constância, repetem os sábios judeus: Shemáh Israel! Dar ouvidos é uma necessidade da fé e do diálogo com Deus. No Ocidente, a leitura em voz alta, com caráter espiritual, institucionalizou-se na regra monástica de São Bento, formulada na primeira metade do século VI. "Bento decretou que a leitura seria uma parte da vida diária do mosteiro" (MANGUEL, 1999, p.137). O hebdomadário escolhido, no domingo, durante toda a semana, deverá ler o livro escolhido pelo abade. Manguel extraiu da 
regra beneditina o artigo 38 que explicitava o procedimento:

Na hora da refeição dos irmãos, sempre haverá leitura; [...] E deverá haver o maior silêncio à mesa, de tal forma que nenhum sussurro ou voz, exceto a do leitor, seja ouvida. E o que quer que seja necessário no tocante à comida, os irmãos deverão passar uns para os outros, de tal forma que ninguém precise pedir nada (MANGUEL, 1999, p.137).

Ao longo do medievo, lectio significa lectio divina. Um lector empresta a sua voz a Deus dirigindo-a a seus companheiros. A lectio implica a escuta. A finalidade de um livro é ser lido em voz alta para um auditório atento. O texto possui um estatuto de oralidade e a leitura implica a voz e a ausculta (LE BRETON, 2016).

Reunir-se para ouvir alguém ler, segundo Manguel (1999), tornou-se também uma prática necessária e comum no mundo laico da Idade Média. Até o aparecimento da imprensa, a alfabetização era rara e os livros, propriedade dos ricos, privilégio de um pequeno punhado de leitores. Mesmo entre esses ricos, ouvir o texto recitado ou lido em voz alta era uma chance usual de se familiarizar com determinado livro ou autor. Havia variadas formas de ouvir um texto. A partir do século XI, em todos os reinos europeus joglars itinerantes recitavam ou cantavam de cor versos de autoria própria ou de mestres trovadores. Nas cortes, e às vezes em casas mais humildes, os livros eram lidos em voz alta para familiares ou amigos, tanto com finalidades de instrução quanto de entretenimento.

Com a invenção da tipografia, a difusão do livro provocou uma conversão dos sentidos, destituindo a audição de suas antigas prerrogativas. Entretanto, a tipografia não atingiu senão uma ínfima parcela da população letrada: “o 'ouvir dizer' continua uma referência” (LE BRETON, 2016, p.46-47). O hábito da leitura ouvida foi transposto para Idade Moderna. Nessa época, eram comuns as leituras públicas informais de novelas de cavalaria e outros textos similares. Ainda no início do século XIX, "quando a noção de uma mulher culta ainda era desaprovada na Inglaterra, ouvir leituras tornou-se uma das maneiras aceitas de estudar" (MANGUEL, 1999, p.143-144).

No Brasil, tanto a leitura ouvida, quanto a leitura de imagens, ainda que circunscritas às esferas religiosas, no espaço dos templos, foram estratégias que permaneceram vigentes a produzir o efeito de educar para a fé, porque, por séculos, não se deu a devida atenção à educação escolarizada e o número dos analfabetos pode, ainda, corresponder com folga à Periódico Horizontes - USF - Itatiba, SP - Brasil - e019039 
população de muitas nações modernas.

\section{Um livro aberto aos sentidos: Nossa Senhora dos Anjos da Porciúncula de Mestre Ataíde}

Um dos mais belos textos pictóricos produzidos pelo barroco brasileiro adorna a Igreja da Ordem Terceira de São Francisco de Assis: a pintura em perspectiva da Assunção de Nossa Senhora, também conhecida sob o título franciscano de Nossa Senhora dos Anjos da Porciúncula. Anteriormente, havíamos mencionado que se trata da mais celebrada obra de Manuel da Costa Ataíde (1762-1830), conhecido como Mestre Ataíde. O artista deu contribuições inestimáveis à ornamentação da igreja: pintou os painéis laterais da capela mor em forma de azulejos, memorando narrativas da vida do patriarca Abraão; alguns quadros e as armas do arco cruzeiro. Mas é no teto da nave que encontramos a realização creditada como "a obra prima do gênero no mundo luso-brasileiro" (OLIVEIRA, 2003, p.280).

A análise técnica da pintura, bem como a sua descrição mais detalhada, inclusive com fotos bastante ilustrativas, foram objeto do trabalho de diversos autores e estudiosos das artes. Destacamos os trabalhos de Oliveira (2003) e de Bazin (1956), ambos por nós utilizados e referidos. No entanto, o leitor que desejar visualizar as fotografias da Igreja de São Francisco de Assis de Ouro Preto e as obras de Mestre Ataíde, podem acessar a "Enciclopédia Itaú Cultural de Arte e Cultura Brasileiras" ${ }^{4}$. Desta forma, podemos nos ater aos pontos mais focais para cumprir os objetivos a que nos propusemos.

A cena da Assunção, recorrente naquela época, ainda que o dogma só tenha sido oficialmente declarado em 1950, por Pio XII, representa uma antiga posição teológica da Igreja defendida desde os primeiros séculos do cristianismo. A Assunção está indissociavelmente ligada à Conceição Imaculada da Virgem Maria, doutrina tão antiga quanto a Assunção, sem que, contudo, fosse unânime ou imune a controvérsias. Ambas se tornaram também caras aos franciscanos e imbricaram-se a sua história, iniciada no século XIII, havendo de ser esses frades reconhecidos como os seus grandes defensores e divulgadores, dentre os quais deve ser

\footnotetext{
${ }^{4}$ IGREJA de São Francisco de Assis (Ouro Preto, MG). In: ENCICLOPÉDIA Itaú Cultural de Arte e Cultura Brasileiras. São Paulo: Itaú Cultural, 2017. Disponível em: http://enciclopedia.itaucultural.org.br/instituicao227359/igreja-desao-francisco-de-assis-ouro-preto-mg. Acesso em: 02 mai. 2018.
}

Periódico Horizontes - USF - Itatiba, SP - Brasil - e019039 
destacado o frade escocês Duns Scotus. Toda a Ordem Franciscana, em geral, aceitou a doutrina de seu mestre, cognominado de Doutor Mariano, de forma que, em pouco tempo, a Imaculada Conceição foi chamada de "opinião franciscana", nome com que foi designada até a definição dogmática.

Após a fundação da Ordem, São Francisco demonstrou grande apreço a uma pequena ermida, muito destruída a encontrou, nas cercanias de Assis, dedicada a Nossa Senhora dos Anjos. A esse lugar, pequeno e muito pobre, chamou-o, por isso, de Porciúncula, e o instituiu para servir de referência de humildade e pobreza à Ordem. Nascia, então, sob a inspiração de São Francisco, um novo título da Virgem, Nossa Senhora dos Anjos da Porciúncula. Também Santo Antônio de Lisboa, primeiro teólogo da Ordem Franciscana a ocupar a função de professor, tinha arraigada devoção a Nossa Senhora Assunta ou da Glória, como também é conhecida. Os títulos de Maria variam, mas expressam o mesmo dogma: a Virgem Maria, Mãe de Deus, em Jesus Cristo, concebida sem pecado original para gerar o Filho encarnado, na sua morte, teve o corpo incorrupto elevado aos Céus.

A Igreja de São Francisco de Assis, em Ouro Preto, construída entre 1766 e 1810, não pertenceu a uma das Ordens de frades franciscanos. Pois sabemos que as Ordens religiosas que atuavam no Brasil foram proibidas de entrar em Minas Gerais. A construção da igreja foi encargo assumido pela Ordem Terceira da Penitência, fundada e organizada por leigos, da forma comuníssima com que eram eretas as muitas e variadas irmandades e confrarias laicas que deixaram marcas indeléveis no nosso catolicismo. Portanto, a decoração da igreja ostentará as temáticas da espiritualidade franciscana, incluindo a apoteótica composição de Ataíde representando a Assunção de Maria Santíssima elevada aos Céus para ser coroada de glória pelos anjos.

A pintura, no entanto, guarda um estilo todo próprio. A virgem aparece rodeada por uma orquestra de anjos músicos de todas as idades com feições mestiças e pele parda. O rosto da Virgem é redondo, os olhos negros, as sobrancelhas finas, separadas e arqueadas, o nariz levemente achatado e os cabelos são crespos. Del Negro (1958, p.54) acrescenta outros detalhes: "cheia de corpo, seios volumosos, colo roliço, rosto amplo, envolve-nos de serenidade e meiguice. Formas robustas e bem proporcionadas sugerem antes beleza louçã que espiritualidade". Assentada num trono de nuvens, em atitude de oração, é rodeada por raios de

$$
\text { Periódico Horizontes - USF - Itatiba, SP - Brasil - e019039 }
$$


luz e apoiada em um crescente lunar. A Virgem ocupa a centralidade: em torno dela e por causa dela o movimento da cena acontece. À complexa composição, ricamente colorida e perfeitamente integrada ao conjunto arquitetônico, somam-se outros elementos doutrinais e simbólicos que emolduram a jubilosa cena central: uma vela acesa simboliza o tempo que passa; uma ampulheta caída, a morte; um açoite, a necessidade de penitência. Os santos e mártires que fazem parte do conjunto também trazem consigo significados precisos, conforme a vida que levaram e a obra que deixaram.

Del Negro (s/d) destaca o aspecto inovador da pintura do teto da nave realizado por Ataíde: introduzir no universo iconográfico da pintura religiosa a música. Entra-se no céu ao som musical de uma orquestra celestial, circunstância que revelaria o valor estético e sagrado que esta linguagem adquiriu no simbolismo religioso das Minas Gerais.

Hill (2001), além de perceber a fidedignidade da representação dos instrumentos musicais, afirmou que as partituras pintadas são legíveis, indício de que Ataíde conhecia música e convivia com ela.

Todas as artes no interior do templo se integram e convocam a totalidade dos sentidos a uma percepção sinestésica do mundo fazendo a alma ascender, por degraus sucessivos, até aquele ponto incognoscível e incompreensível que é Deus, da forma com que concebeu o santo escolástico franciscano Boaventura de Bagnoregio (2012), no "Itinerário da Mente para Deus". Lembra Le Breton (2016) que a tradição cristã conserva a doutrina dos sentidos espirituais formulada por Orígenes, retomada por Gregório de Nissa, evocada por Santo Agostinho e desenvolvida por São Boaventura. Os sentidos espirituais são associados à alma. Logo, afirma Le Breton (2016, p.17), “a marca da presença de Deus da qual a sensorialidade profana não saberia prestar contas" irrompe "através de instituições fulgurantes que dão acesso a uma realidade sobrenatural marcada pela presença de Deus". Esta é a função das artes sacras: "formam um sentir da alma próprio a penetrar universos sem comum medida com a dimensão corporal dos outros sentidos" (LE BRETON, 2016, p.17):

Uma visão para contemplar os objetos supracorporais, como é manifestamente o caso para os querubins ou os serafins; um ouvido capaz de distinguir vozes que não ressoam no ar; um paladar para saborear "o pão vivo descido do céu a fim de dar a vida ao mundo" (Jo 6, 33); assim como um olfato que percebe as

Periódico Horizontes - USF - Itatiba, SP - Brasil - e019039 
realidades que levam Paulo a dizer "um bom odor de Cristo" (2 Cor 2, 150); um tato que possuía João quando diz que apalpou com as próprias mãos o Verbo divino (LE BRETON, 2016, p.17).

Como sustenta Pinilla (2002, p.31, tradução minha), não há dúvida de que a Igreja no Novo Mundo empregou as artes plásticas como uma ars memorativa:

A teologia barroca do ícone partia da teoria aristotélica - cristianizada - da percepção e do conhecimento: o que o sentido percebe, a imaginação representa, a cognição forma, a sagacidade investiga, a razão julga, a memória conserva, a inteligência capta e conduz à contemplação' 5 .

Um símbolo, no entanto, poderia produzir múltiplos significados, e enquanto a Igreja tridentina expressava suas verdades eternas em imagens plásticas - método de catequese que julgava infalível - não havia garantias de que estas fossem sempre interpretadas segundo os seus ditames: "[...] esta indeterminação última própria do visual, que aos olhos dos religiosos poderia parecer uma debilidade, constitui precisamente sua riqueza e abre a diferentes leituras possíveis" (PINILLA, 2002, p.29, tradução minha) ${ }^{6}$.

Os religiosos enganaram-se. Não possuíam referenciais teóricos que fossem além da antiga epistemologia escolástica. Entendiam a verdade como adequatio, acreditando haver perfeita correspondência entre a mente e as coisas. Os sentidos não são "janelas" sobre o mundo, "espelhos", oferecidos ao registro das coisas em total indiferença com as culturas ou com as sensibilidades; eles são filtros que só retêm em sua peneira o que o indivíduo aprendeu a colocar nela, ou o que ele justamente busca identificar mobilizando seus recursos. As coisas não existem em si, elas são sempre investidas de um olhar, de um valor que as torna dignas de serem percebidas. A configuração e o limite do desdobramento dos sentidos pertencem ao traçado da simbologia social (LE BRETON, 2016, p.15).

As percepções sensoriais não dependem somente de uma fisiologia, mas "em primeiro lugar de uma orientação cultural deixando uma margem à sensibilidade individual" (LE BRETON, 2016,

\footnotetext{
${ }^{5}$ La teología barroca del icono partía de la teoría aristotélica - cristianizada - de la percepción y el conocimiento: ‘o que el sentido percibe, la imaginación representa, la cognición forma, el ingenio investiga, la razón juzga, la memoria conserva, la inteligencia capta y conduce a la contemplación'.

${ }^{6}$ [...] esta indeterminación última propia de lo visual, que a los ojos de los religiosos podría parecer una debilidad, constituye precisamente su riqueza y abre a las diferentes lecturas posibles.
}

Periódico Horizontes - USF - Itatiba, SP - Brasil - e019039 
p.14). As percepções sensoriais formam um prisma de significações sobre o mundo e são modeladas pela educação e utilizadas segundo a história pessoal. Portanto, numa mesma comunidade elas variam de um indivíduo ao outro, ainda que, basicamente, se acordam sobre o essencial.

Na colônia, a evangelização e a tentativa de aculturação tornam-se muito mais complexas porque se misturam matrizes culturais as mais diversas: indígenas, ibéricas e africanas. E cada um desses grupos, bem como os indivíduos que os integram, habitam universos sensoriais muito diversos. Pois cada uma dessas culturas "determina um campo de possibilidades do visível e do invisível, do tátil e do intocável, do olfato e do inodoro, do sabor e da sensaboria, do límpido e do nebuloso etc." (LE BRETON, 2016, p.17).

A mestiçagem cultural é um movimento lento, resultado das lutas de resistência dos indivíduos e dos grupos etnossociais marcados por uma história de desterro e por um longo processo de desculturação. Mas também foi uma forma inescapável de produção de novos significados e identificações num contexto social e cultural hostil. Os sentidos se rebelam, se corrigem, se misturam, se reorganizam e se remetem a uma memória ancestral em desagregação e aparentemente perdida, enquanto os condicionantes da experiência atual remodelam a sensibilidade e produzem novos sentidos estéticos que compõem e decompõem identidades e nexos existenciais capazes de ler e reler o mundo colonial.

\section{Considerações finais}

O complexo barroco que fomos capazes de criar foi o resultado de entrecruzamentos e de mesclas de influências, a priori, improváveis. A feição impura, mestiça, diversa e popular é que o torna único e incomparável. A arte barroca franciscana teve o mérito de amalgamar-se ao gosto e às lutas populares. Encontramos, na simbologia e na dicção franciscanas, outras formas de textualidade apreendidas e reelaboradas pelos sentidos, de modo potente, criativo e seminal.

Educar pela arte, dando-Ihe forte apelo estético à sensorialidade, através da produção de uma escrita pictórica, sonora, visual, foi uma estratégia promissora e, aparentemente, eficaz dos dominadores para aculturarem indígenas, negros, crioulos e mestiços. Mas as expressões artísticas protagonizadas pelos artistas populares logo se tornam incontroláveis, e, de certo modo, incognoscíveis aos detentores dos códigos canônicos da arte, porque as luzes, as cores,

$$
\text { Periódico Horizontes - USF - Itatiba, SP - Brasil - e019039 }
$$


as texturas, os sons, os olores, as formas, os sabores abriram as portas da percepção a outros mundos possíveis de significados. É nesse sentido que o sincretismo toma a forma de resistência cultural e é uma das mais genuínas e belas expressões da nossa cultura.

A arte barroca, igualmente, foi pródiga na tentativa de emprestar novos sentidos à existência no mundo colonial. Tratou-se de buscar uma linguagem (pela palavra, música, pintura, dança, escultura, arquitetura etc.) capaz de enunciar o desejo de superação do cotidiano vulgar e óbvio das coisas que pareceram ordenadas a um destino predeterminado e pouco promissor. Pela arte foi possível resistir e transcender a banalidade da violência, da exclusão e da morte. No contexto colonial, as expressões artísticas populares ou aquelas direcionadas ao povo foram bastante eficazes e potentes para firmar processos educacionais informais que não puderam passar pelo interior da escola.

\section{Referências}

AMORIM, M. A. Os franciscanos no Maranhão e Grão-Pará: missão e cultura na primeira metade do seiscentos. Lisboa: CEHR, 2005.

ARAUJO, E. (Org.). A mão afro-brasileira: significado da contribuição artística e histórica. 2. ed. São Paulo: Imprensa Oficial do Estado de São Paulo/Museu Afro Brasil, 2010.

BAGNOREGGIO, B. Itinerário da Mente para Deus. Petrópolis: Vozes, 2012.

BAZIN, G. A arquitetura religiosa barroca no Brasil. Rio de Janeiro: Record, 1956.

BOSI, A. Dialética da colonização. 4. ed. São Paulo: Companhia das Letras, 2009.

BRANDÃO, R. O. Poética e poesia no Brasil colônia. São Paulo: UNESP/Imprensa Oficial do Estado, 2001.

CASTAGNA, P. Avanços e perspectivas na musicologia histórica brasileira. In: Revista do Conservatório de Música da UFPel. Pelotas, v.1, n.1, p.32-57, 2008.

CONCHA, J. N. Historiografía de la arquitectura durante el período Virreinal em América del Sur: discursos, textos y contextos. 2013. 572f. Tese (Doutorado em História del Arte) - Universidad de Granada. Granada, 2013.

COSTA, M. C. C. A imagem da mulher: um estudo de arte brasileira. Rio de Janeiro: Senac Rio, 2002.

Periódico Horizontes - USF - Itatiba, SP - Brasil - e019039 
D'ARAUJO, A. L. Arte no Brasil colonial. Rio de Janeiro: Revan, 2000.

DEL NEGRO, C. Contribuição ao estudo da pintura mineira. Rio de Janeiro: Diretoria do Patrimônio Histórico e Artístico Nacional, 1958.

DEL NEGRO, C. Manoel da Costa Athayde: encurralado no Paraíso. Brasília: Instituto de Artes da Universidade de Brasília, s/d.

GASPARINI, G. El amanhecer del Renacimiento em América: una apreciación arquitectónica. Research Institute for de Study of de Man: New York, 1995.

GRUZINSKI, S. A colonização do imaginário: sociedades indígenas e a ocidentalização do México espanhol. São Paulo: Companhia das Letras, 2003.

HILL, M. Algumas obras do pintor Manuel da Costa Ataíde e seus comentários. Cultura Visual, Salvador, v.1, n.3, p.123-148, jan./jul. 2001.

HOLANDA, S. B. Capítulos da literatura colonial. São Paulo: Brasiliense, 1991.

HOLANDA, S. B. Raízes do Brasil. 26. ed. São Paulo: Companhia das Letras,1995.

INSTITUTO CULTURAL ITAÚ - ICl. Cadernos história da pintura no Brasil: pintura colonial, n.7, São Paulo: ICl, 1994.

IGREJA de São Francisco de Assis (Ouro Preto, MG). In: ENCICLOPÉDIA Itaú Cultural de Arte e Cultura Brasileiras. São Paulo: Itaú Cultural, 2017. Disponível em:

http://enciclopedia.itaucultural.org.br/instituicao227359/igreja-de-sao-francisco-de-assis-ouropreto-mg. Acesso em: 2 mai. 2018.

JABOATÃO, Frei A. S. M. Jaboatão místico em correntes sacras dividido. Lisboa: Off. de Antonio Vicente da Silva, 1758.

LE BRETON, D. Antropologia dos sentidos. Petrópolis: Vozes, 2016.

MANGUEL, A. Uma história da leitura. São Paulo: Companhia das Letras, 1999.

NÓBREGA, M. Cartas do Brasil e mais escritos do Padre Manuel da Nóbrega (Opera Omnia): introdução e notas históricas e críticas do Padre Serafim Leite. Coimbra: Universidade, 1955.

OLIVEIRA, C. M. S. Arte colonial e mestiçagem no Brasil setecentista: irmandades, artífices, anonimato e modelos europeus nas capitanias de Minas e do norte do Estado do Brasil. In: PAIVA, E. F.; AMANTINO, M.; IVO, I. P. (Orgs.). Escravidão, mestiçagens, ambientes, paisagens e espaços. São Paulo: Annablume, 2011. p.95-113. 
OLIVEIRA, M. A. R. O rococó religioso no Brasil e seus antecedentes europeus. São Paulo: Cosac \& Naify, 2003.

PINILLA, R. M. Arte e identidad: las raíces culturais del barroco peruano. In PINILA, R. M. et Alii. El barroco peruano. Lima: Banco de Crédito del Perú, 2002, p.1-57.

RÖWER, B. A Ordem Franciscana no Brasil. Petrópolis: Vozes, 1947.

SEVCENKO, N. Pindorama revisitada: cultura e sociedade em tempos de virada. 2 ed. São Paulo: Peirópolis, 2000.

SOUSA, A. A invenção do barroco brasileiro: a igreja franciscana de Cairu. João Pessoa: Ed. Universitária/UFPB, 2005.

TAPIÉ, V. L. Barroco e classicismo. Madrid: Cátedra, 1991.

VAINFAS, R. A tessitura dos sincretismos: mediadores e mesclas culturais. In: FRAGOSO, J.; GOUVÊA, M. F. O Brasil colonial: 1443-1580. vol. 1. Rio de Janeiro: Civilização Brasileira, 2014. p.357-388.

Recebido em maio de 2018.

Aprovado em março de 2019. 